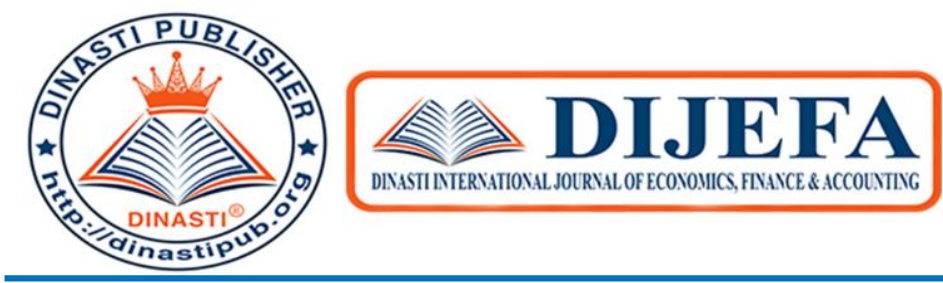

+6281387654578 (9)

+6281387654578 @

https://dinastipub.org/DIJEFA (2)

dinasti-info@gmail.com (๑)

THE EFFECT OF DEBT TO EQUITY RATIO, NET PROFIT MARGIN AND

EARNING PER SHARE ON SHARE PRICES IN CHEMICAL SUBSECTOR

COMPANIES IN SOUTHEAST ASIA 2012 - 2018 (Case Study of a Company Listed on the Southeast Asian Stock Exchange)

\title{
Deni Sunaryo
}

Universitas Serang Raya, Banten, Indonesia

ARTICLE INFORMATION

Received: 28 September 2020

Revised: 20 October 2020

Issued: 28 November 2020

Corresponding author: first author

E-mail:

denisunaryomm@gmail.com

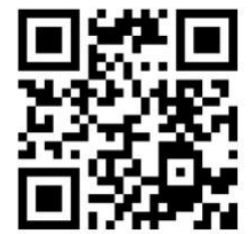

DOI: 10.38035/DIJEFA
Abstract: This study aims to analyze the effect of Debt to Equity Ratio (DER), Net Profit Margin (NPM) and Earning Per Share (EPS) simultaneously or partially on stock prices in chemical subsector manufacturing companies listed on the Southeast Asian Stock Exchange in 2012. -2018. The population is chemical sub-sector companies listed on the Southeast Asian Stock Exchange from 2012 to 2018. The research sample was 11 companies in the chemical sub-sector obtained by using purposive sampling technique. The data collection technique uses the documentation method, while the data analysis technique uses multiple linear regression analysis which is supported by the classical assumption test, namely the normality test, multicollinearity test, heteroscedasticity test, and autocorrelation test. The results showed that partially the DER variable, EPS had a significant positive effect, and the NPM variable had a significant negative effect. Simultaneously, DER, NPM, and EPS variables have a significant effect on stock prices. The R Square value of 0.114 indicates that the DER, NPM, and EPS variables are $11.4 \%$, while the remaining $88.6 \%$ are influenced by other variables outside the regression model.

Keywords: Debt to Equity Ratio (DER), Net Profit Margin (NPM) and Earning Per Share (EPS) and Stock Prices..

\section{INTRODUCTION}

The progress and development of the business world which is increasingly fast encouraging international trade which greatly affects the economy of a country, by improving the products produced or the services provided to consumers. These improvements certainly 
require a lot of funding. Therefore, the capital market plays an important role for companies, apart from being an external financing, market capital can also be used as a vehicle for public investment.

Chemical companies in Southeast Asia are cooperative in terms of cooperation, of course, need a variety of production factors to support their operational activities, one of which is capital or funding. Sources of funding come from within the company and outside the company. Funding within the company uses the company's retained earnings, while from outside it is in the form of debt and funding in the form of shares. Funding through the participation mechanism is carried out by selling the company's shares to the public which is known as going public.

The International Capital Market is an international trading system within the scope of the world economy, which directly or indirectly involves every country in the world to carry out an international trade coordination. The capital market (capital market) is a market for a variety of long-term financial instruments that can be traded, both debt securities (bonds), equities (stocks), mutual funds, derivative instruments and other instruments. Financial instruments traded on the capital market are long-term instruments (with a term of more than 1 year) such as stocks, bonds, warrants, rights, mutual funds, and various derivative instruments such as options, futures, and others.

The capital market and the securities industry are indicators to assess a country's economy is running well or not. This is possible because the capital market is an important financial instrument in an economy that functions to regulate the transfer of funds from the public to the productive sector (companies). One of the capital market instruments that encourage the development of a company is the stock assessing the financial condition of a company, it can use certain measures. The measures used in this study are the liquidity ratio, the leverage ratio (Debt to Equity Ratio), the activity ratio, the profit ratio (Net Profit Margin and Earning Per Share) and the assessment ratio.

Share price is the price of a share on the ongoing market on the stock exchange. Shareholders will receive a return on their capital in the form of dividends and capital gain. (Sunariyah, 2006). The high share price will reduce the ability of investors to buy the share price.

Debt to equity ratio (DER) or in Indonesian called the ratio of debt to equity or ratio of debt to equity is a financial ratio that shows the relative proportion of equity and debt used to finance a company's assets (Kho, 2017). Net Profit Margin is the company's ability to generate profits compared to sales achieved.

Earnings per share (EPS) or in Indonesian, often referred to as earnings per share, is a calculation ratio used to assess profitability or to show the profits of a company obtained from allocations to each outstanding share (Sulistiyo, 2018).

Explained Debt to Equity Ratio (DER) with a number below 1.00, indicating that the company has a debt that is smaller than its capital (equity). The higher the DER, the greater the total debt composition (short term and long term) compared to the total equity itself, so that it has a greater impact on the company's burden on outsiders (creditors). In the journal Ansal Lacinka, Aziz Fathoni, Edward Gagah (2018) The results of this study show that in investing, investors do not pay attention to DER as one of the considerations in making their investment decisions because every increase or decrease in DER does not affect changes in stock prices. 
The greater the Net Profit Margin, the healthier the company. If the Net Profit Margin is small, if there is a decrease in price, the profit will be smaller and it could lead to loss. To see the company's performance, companies usually compare Net Profit Margin for several consecutive years. From this data, if the number goes up, we can analyze what income has increased or if what burden has decreased. Conversely, if the number is decreasing, we can analyze what income has decreased or what expenditure has increased which causes profit to decrease. In the journal Ansal Lacinka, Aziz Fathoni, Edward Gagah (2018) if the NPM goes up, the stock price will increase. The results of this NPM have a low effect on stock prices so that the company's ability to earn profits is also low.

In terms of earnings ratio, it is used to examine the underlying causes of changes in EPS. These earnings ratios show the combined impact of liquidity and asset / liability management on a company's ability to generate profits. These ratios break down EPS into its basic determinants in order to assess the factors that underlie corporate profits. These ratios help in assessing the adequacy of historical earnings and projecting future earnings through a better understanding of the causes of earnings.

Earnings per share can measure the acquisition of each investment unit in the net profit of a business entity in a certain period. The size of the earnings per share is influenced by changes in the variables. Any change in net income or the number of ordinary shares outstanding can result in a change in earnings per share (EPS).

Based on the three measuring tools Debt to Equity Ratio, Net Profit Margin, and Earning Per Share as independent variables and stock prices as the dependent variable, the authors are interested in taking the title "The Effect of Debt To Equity Ratio (DER), Net Profit Margin (NPM), and Earning Per Share (EPS) Against Share Prices in Manufacturing Companies Listed in Chemicals in Southeast Asia".

\section{LITERATURE REVIEW \\ Debt To Equity Ratio (DER)}

According to Kasmir (2018: 157), "Debt to Equity Ratio is a ratio used to assess debt and equity. This ratio is found by comparing all debt, including current debt, and total equity. This ratio is useful for knowing the amount of funds provided by the borrower (creditor) and the company owner. In other words, this ratio serves to find out every rupiah of own capital used as collateral for debt".

Here is the DER formula:

$$
\begin{aligned}
& \text { Debt to Equity Ratio } \\
& \text { (DER) }=
\end{aligned}
$$

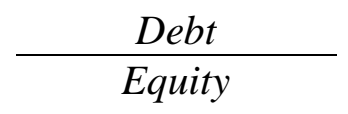

\section{Net Profit Margin (NPM)}

According to Fahmi (2018: 137) Net Profit Margin or net profit margin is also called the revenue to sales ratio. The method of measuring this ratio is to compare net income after tax with net sales.

Here is the NPM formula:

$$
\text { NPM }=\frac{\text { Net Profit After Tax }}{\text { Net sales }}
$$




\section{Earning Per Share (EPS)}

Earning Per Share or income per share is a form of giving benefits to shareholders from each share they own (Fahmi, 2018: 138).

Here is the EPS formula:

$$
\text { EPS }=\frac{\text { EAT }}{\text { Amount of shares outstanding }}=\mathrm{Rp} \ldots / \text { sheet }
$$

\section{RESEARCH METHODS}

The research method aims to examine the effect of debt to equity ratio, net profit margin, and earnings per share on stock prices in chemical sub-sector companies in Southeast Asia from 2012 to 2018. The type of data used in this study is quantitative data and is secondary data, obtained from chemical sector companies listed on the Southeast Asian Stock Exchange (BEI, SGX, HOSE / HSX, and MYX). This research will use quantitative methods. Quantitative methods are called traditional methods, because this method has been used for a long time so that it has become a traditional method for research.

\section{FINDINGS AND DISCUSSION}

\section{Population and Sample}

The population used in this study is the financial statements of the chemical subsector companies listed on the Southeast Asian Stock Exchange as many as 65 companies. The samples used in this study were 11 companies with complete financial reports from the 20122018 research year.

Table 1 List of Companies in the Food and Beverage Subsector which were the research samples for the 2012 - 2018 period

\begin{tabular}{|c|c|c|}
\hline NO & COUNTRY & NAME OF COMPANY \\
\hline 1 & \multirow{3}{*}{ Indonesia } & PT. Budi Acid Jaya Tbk \\
\hline 2 & & PT. Ekadharma Internasional Tbk \\
\hline 3 & & PT. Indo Acidatama Tbk \\
\hline 4 & \multirow{3}{*}{ Thailand } & PTT Global Chemical Public Company \\
\hline 5 & & Thai Central Chemical Public Company \\
\hline 6 & & Union Petrochemical Public Company \\
\hline 7 & \multirow{3}{*}{ Malaysia } & Petronas Chemical Group Bhd \\
\hline 8 & & Chemical Company Of Malaysia Bhd \\
\hline 9 & & Imaspro Corporation Bhd \\
\hline 10 & Singapore & China Sunsine Chemical Holdings Ltd \\
\hline 11 & Vietnam & Binh Minh Plastics Joint Stock Com \\
\hline
\end{tabular}




\section{Discussion}

\section{Descriptive Statistics of Research Variables}

Table 2 Descriptive Statistics of Research Variables

Descriptive Statistics

\begin{tabular}{|l|r|r|r|r|r|}
\hline & \multicolumn{1}{|c|}{ N } & Minimum & Maximum & \multicolumn{1}{c|}{ Mean } & Std. Deviation \\
\hline ROA & 168 &,- 004 &, 390 &, 13429 &, 086172 \\
CR & 168 &, 60 & 8,64 & 2,2542 & 1,46510 \\
DER & 168 &, 12 & 5,30 &, 9487 &, 88009 \\
TATO & 168 &, 30 & 2,90 & 1,1646 &, 50888 \\
Valid N (listwise) & 168 & & & & \\
\hline
\end{tabular}

Source: Results of data processing SPSS V 23

Based on the results of statistical analysis, it shows that:

a) During 2012 to 2018 the minimum value of the Debt To Equity Ratio (DER) variable is 0.050 , the maximum DER value is 100,000 . The mean DER value is 1.85753 and the standard deviation value is 11.34362 with 77 observation data.

b) During 2012 to 2018 the minimum value of the Net Profit Margin (NPM) variable was 0.020 , the maximum NPM value was 740,000 , the mean NPM value was 14.39416 and the standard deviation value was 84.174250 with 77 observation data.

c) During 2012 to 2018 the minimum value of the Eaening Per Share (EPS) variable was -9,290, the maximum EPS value was 701,060, the mean EPS value was 28.75403 and the standard deviation value was 82.992458 with 77 observation data.

d) During 2012 to 2018, the minimum variable value of the Stock Price was 0.099, the maximum value of the Share Price was 855,000, the mean value of the Share Price was 77.76434 and the standard deviation value was 160.113910 with 77 observation data.

Classic assumption test

Normality test

Figure 1 Test Histogram

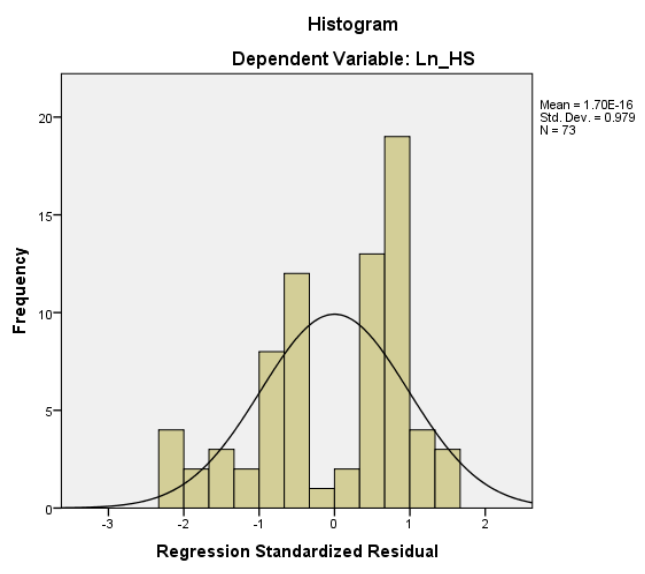

Source: Results of data processing SPSS V 23

Figure 2 P-Plot of SPSS Normality Test 


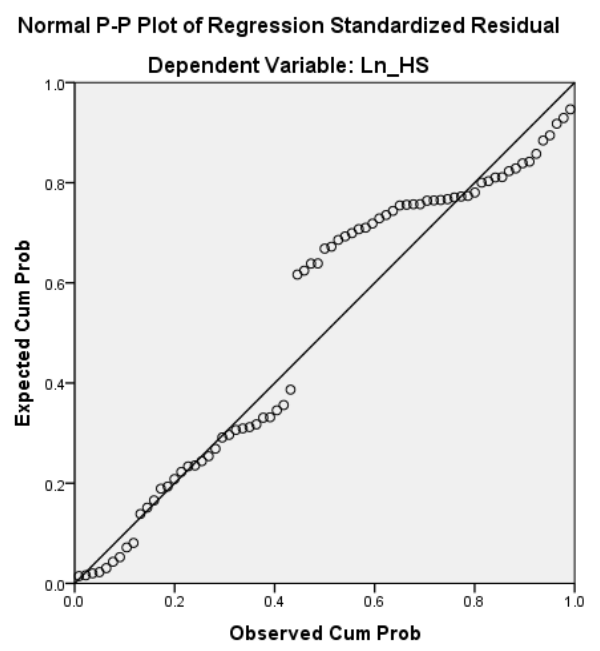

Source: Results of data processing SPSS V 23

From the normality test, histogram graph and SPSS P-Plot it can be concluded that the regression model fulfills the assumption of normality, it can be seen that the results of statistical tests (preferably only use graph tests) the results of the graph test above show that if the normality test is met it can be seen from the graph that forms a bell follow the diagonal line. The curves on the histogram graph form a bell pattern and then in the image the points appear to follow and approach the diagonal line.

\section{Multicollinearity Test}

Table 3 Multicollinearity Test

\begin{tabular}{|c|c|c|c|c|c|c|c|c|}
\hline \multicolumn{9}{|c|}{ Coefficients $^{a}$} \\
\hline \multirow{2}{*}{\multicolumn{2}{|c|}{ Model }} & \multicolumn{2}{|c|}{ Unstandardized Coefficients } & \multirow{2}{*}{$\begin{array}{c}\begin{array}{c}\text { Standardized } \\
\text { Coefficients }\end{array} \\
\text { Beta }\end{array}$} & \multirow[b]{2}{*}{$t$} & \multirow[b]{2}{*}{ Sig. } & \multicolumn{2}{|c|}{ Collinearity Statistics } \\
\hline & & $B$ & Std. Error & & & & Tolerance & VIF \\
\hline \multirow[t]{4}{*}{1} & (Constant) & 2.219 & .465 & & 4.773 & .000 & & \\
\hline & Ln_EPS & .473 & .169 & .361 & 2.794 & .007 & .771 & 1.297 \\
\hline & Ln_DER & .622 & .311 & .247 & 2.000 & .049 & .845 & 1.184 \\
\hline & Ln_NPM & -.084 & .120 & -.085 & -.705 & .483 & .881 & 1.135 \\
\hline
\end{tabular}

a. Dependent Variable: Ln_HS

Source: Results of data processing SPSS V 23

From the multicollinearity test table, it can be concluded that the results are fulfilled because each variable has a tolerance value greater than 0.10 and a VIF value below $<10$. 


\section{Heteroscedasticity Test}

Figure 3 Heteroscedasticity Test

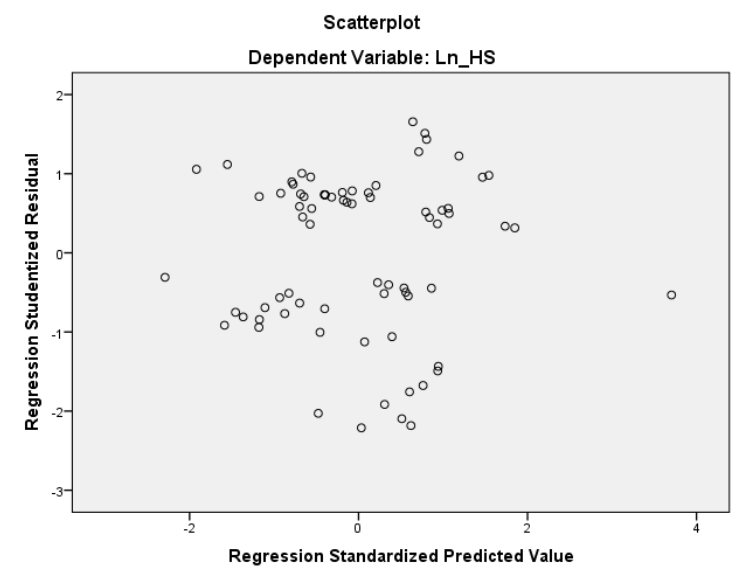

Source: Results of data processing SPSS V 23

The heteroscedasticity test image shows that the data has spread below and above zero and does not form a pattern.

\section{Autocorrelation Test}

Table 4 Autocorrelation Test

Model Summary ${ }^{\mathrm{b}}$

\begin{tabular}{|l|l|r|r|r|r|}
\hline Model & $\mathrm{R}$ & R Square & $\begin{array}{c}\text { Adjusted R } \\
\text { Square }\end{array}$ & $\begin{array}{c}\text { Std. Error of } \\
\text { the Estimate }\end{array}$ & $\begin{array}{c}\text { Durbin- } \\
\text { Watson }\end{array}$ \\
\hline 1 & $.293^{\mathrm{a}}$ & .086 & .044 & 2.21276 & 1.765 \\
\hline
\end{tabular}

a. Predictors: (Constant), lag_EPS, lag_NPM, lag_DER

b. Dependent Variable: lag_HS

Source: Results of data processing SPSS V 23

The autocorrelation test results show the durbine watson (DW) value of 1.765 which indicates that the DW value is between du (1.70667) to 4-du (2.29333). The DW value is in an area where there is no positive or negative autocorrelation.

\section{Multiple Regression Analysis}

Partial Significance Test (t-test)

Table 5 Results of Multiple Regression Analysis and t-test

\begin{tabular}{|c|c|c|c|c|c|c|}
\hline & & \multicolumn{5}{|c|}{ Coefficients $\mathrm{s}^{\mathrm{a}}$} \\
\hline \multirow[b]{2}{*}{ Mod } & & \multicolumn{2}{|c|}{ Unstandardized Coefficients } & \multirow{2}{*}{$\begin{array}{c}\begin{array}{c}\text { Standardized } \\
\text { Coefficients }\end{array} \\
\text { Beta }\end{array}$} & \multirow[b]{2}{*}{ t } & \multirow[b]{2}{*}{ Sig. } \\
\hline & & $B$ & Std. Error & & & \\
\hline \multirow[t]{4}{*}{1} & (Constant) & 2.219 & .465 & & 4.773 & .000 \\
\hline & Ln_EPS & .473 & .169 & .361 & 2.794 & .007 \\
\hline & Ln_DER & .622 & 311 & .247 & 2.000 & .049 \\
\hline & Ln_NPM & -.084 & .120 & -.085 & -.705 & .483 \\
\hline
\end{tabular}

a. Dependent Variable: Ln_HS

Source: Results of data processing SPSS V 23

The $t$ test results show that the $t$ value is smaller than the $t$ table in hypotheses 1 and $2(2.794$ / 2,000> 1.99394) and the significance value is less than $0.05(0.007 / 0.049<0.05)$. Whereas in hypothesis 3 the $t$ value is smaller than the table value $(0.705<1.99394)$ and the 
significance value is greater than $0.05(0.483>0.05)$. This means that hypotheses 1 and 2 are accepted / supported and hypothesis 3 is not accepted / supported.

\section{Partial Significance Test (F-Test)}

Table 6 F-Test Results

ANOVA $^{\mathrm{a}}$

\begin{tabular}{|rl|r|r|r|r|r|}
\hline \multicolumn{2}{|c|}{} & \multicolumn{1}{c|}{$\begin{array}{c}\text { Sum of } \\
\text { Squares }\end{array}$} & df & Mean Square & F & Sig. \\
\hline 1 & Regression & 45.345 & 3 & 15.115 & 2.960 & $.038^{\text {b }}$ \\
& Residual & 352.370 & 69 & 5.107 & & \\
& Total & 397.716 & 72 & & & \\
\hline
\end{tabular}

a. Dependent Variable: Ln_HS

b. Predictors: (Constant), Ln_NPM, Ln_DER, Ln_EPS

Source: Results of data processing SPSS V 23

Based on table 5, the results of the SPSS version 23 test above the F test results show that the calculated $F$ value is greater than the $F$ table value, namely $2.960>2.73$, and the significance value is smaller than $0.05(0.038<0.05)$. it means that all $\mathrm{X}$ variables simultaneously influence Y.

\section{Coefficient of Determination (R2)}

Table 7 Results of the Coefficient of Determination (R2)

Model Summary

\begin{tabular}{|l|l|l|r|r|}
\hline Model & $\mathrm{R}$ & R Square & $\begin{array}{c}\text { Adjusted R } \\
\text { Square }\end{array}$ & $\begin{array}{c}\text { Std. Error of } \\
\text { the Estimate }\end{array}$ \\
\hline 1 & $.338^{\mathrm{a}}$ & .114 & .075 & 2.25983 \\
\hline
\end{tabular}

a. Predictors: (Constant), Ln_NPM, Ln_DER, Ln_EPS

b. Dependent Variable: Ln_HS

Source: Results of data processing SPSS V 23

Based on table 6 above, variable $\mathrm{Y}$ is influenced by all $\mathrm{X}$ variables by $11.4 \%$, the remaining $88.6 \%$ is influenced by other variables outside of this study.

\section{CONCLUSION AND SUGESTION}

Based on the discussion of the research results that have been described, it can be concluded that:

1. Debt to Equity Ratio partially has a significant effect on stock prices.

2. Partially Net Profit Margin has no significant effect on stock prices.

3. Partially Earning Per Share has a significant effect on stock prices.

4. Debt to Equity Ratio, Net Profit Margin, and Earning Per Share simultaneously have a significant effect on share prices in chemical sub-sector companies listed on the Southeast Asian Stock Exchange from 2012 to 2018.

\section{REFERENCE}

Darmadji, Tjiptono dan Hendy M. Fakhruddin. (2001). Pasar Modal di Indoneisa: Pendekatan Tanya Jawab. Jakarta: Salemba Empat.

Fahmi, Irham 2018, Pengantar Manajemen Keuangan, Bandung: Alfabeta. 
Fauziyyah, Nurul, Ghaida. 2017. Pengaruh Perputaran Modal Kerja Terhadap Rentabilitas Ekonomi Pada Perusahaan Sub Sektor Semen Yang Terdaftar di BEI Periode 20112015. Skripsi. Universitas Sarjanaiyata Tamansiswa.

Frendy Sondakh, dkk. 2015. Curret Ratio, Debt to Equity Ratio, Return On Asset, Return On Equity Pengaruhnya Terhadap Harga Saham Pada Indeks LQ45 Di BEI Periode 2010 2014.

Ghozali, Imam. 2011. Aplikasi Analisis Mutivariate Dengan Program IBM SPSS 19. Edisi kelima. Penerbit Universitas Dipenegoro : Semarang.

Hermuningsih, Sri. (2012). Pengantar Pasar Modal Indonesia. Yogyakarta. UPP STIM YKPN.

Kasmir. 2018. Analisis Laporan Keuangan cetakan ke tujuh - delapan. Jakarta: Raja Grafindo Persada.

Khan, M. N., \& Amanulah. (2012). "Determinants of share prices at Karachi Stock Exchange. International Journal of Business and Management Studies", 4(1), 111-120.

Seetharaman and John Rudolph Raj, 2011. An Empirical Study on the Impact of Earnings per Share on Stock Prices of a Listed Bank in Malaysia. The International Journal of Applied Economics and Finance, 5: 114-126.

Sugiyono. 2014. Metode Penelitian Bisnis. Edisi Revisi. Penerbit Alfabeta. Bandung.

Sumaryati. 2016. Pengaruh EVA dan Profitabilitas terhadap Harga Saham pada Perusahaan Manufaktur Sektor Industri Makanan dan Minuman yang Terdaftar di BEI Tahun 20102014. Skripsi. Universitas Sarjanawiyata Tamansiswa.

Tandelilin, Eduardus. (2001). Analisis Investasi dan Manajemen Portofolio. Yogyakarta: BPFE-UGM.

Wuryaningrum, Reni. 2015. Pengaruh Rasio Keuangan Terhadap Harga Saham Pada Perusahaan Farmasi Di Bei. Skripsi. Universitas Sarjanawiyata Tamansiswa.

Wahyuni. (2014). "Pengaruh Inventory Turnover, Debt To Equity Ratio (DER), Return On Equity (ROE), dan Earning Per Share (EPS) Terhadap Harga Saham Pada Perusahaan Manufaktur Yang Terdaftar di BEI Tahun 2009-2012”. Skripsi. Universitas Negeri Yogyakarta

Source of Internet :

www.idx.co.id

www.sgx.com

www.bursamalaysia.com

www.hsx.vn 